\title{
Inflammation, T-Cell Phenotype, and Inflammatory Cytokines in Chronic Kidney Disease Patients Under Hemodialysis and its Relationship to Resistance to Recombinant Human Erythropoietin Therapy
}

\author{
Elísio Costa • Margarida Lima • João Moura Alves • \\ Susana Rocha • Petronila Rocha-Pereira • \\ Elisabeth Castro • Vasco Miranda • \\ Maria do Sameiro Faria • Alfredo Loureiro • \\ Alexandre Quintanilha • Luís Belo • Alice Santos-Silva
}

Received: 9 November 2007 / Accepted: 28 December 2007

(C) Springer Science + Business Media, LLC 2008

\begin{abstract}
Background Resistance to recombinant human erythropoietin (rhEPO) occurs in some chronic kidney disease (CKD) patients, which may be due to enhanced systemic inflammatory response and to the erythropoiesis-suppressing effect of pro-inflammatory cytokines, some of which are produced by $\mathrm{T}$ cells.

Aim of study The aim of this study was to investigate the relationship between resistance to rhEPO therapy in hemodialysis $\mathrm{CKD}$ patients and inflammatory markers $[\mathrm{C}$ reactive protein (CRP), soluble interleukin (IL)-2 receptor (sIL2R), and serum albumin levels], blood cell counts, T-
\end{abstract}

E. Costa $(\bowtie) \cdot$ S. Rocha $\cdot$ E. Castro $\cdot$ L. Belo $\cdot$ A. Santos-Silva Serviço de Bioquímica,

Faculdade de Farmácia da Universidade do Porto,

Rua Aníbal Cunha, 164,

4099-030 Porto, Portugal

e-mail: elisio.costa@ipb.pt

E. Costa $\cdot$ S. Rocha $\cdot$ P. Rocha-Pereira $\cdot$ E. Castro $\cdot$

A. Quintanilha $\cdot$ L. Belo $\cdot$ A. Santos-Silva

Instituto de Biologia Molecular e Celular (IBMC),

Universidade do Porto,

Porto, Portugal

E. Costa

Departamento de Tecnologias de Diagnóstico e Terapêutica, Escola Superior de Saúde, Instituto Politécnico de Bragança,

Porto, Portugal

M. Lima $\cdot$ J. M. Alves

Laboratório de Citometria, Hospital Geral Santo António, HGSA,

Porto, Portugal cell phenotype, cytokine production by $\mathrm{T}$ cells, and serum cytokine levels.

Materials and Methods We studied 50 hemodialysis CKD patients, 25 responders and 25 nonresponders to rhEPO, and compared them to each other and with 25 healthy controls. When compared to controls, CKD patients showed increased serum levels of CRP, IL-6, and sIL2R and a T-cell lymphopenia, due to decreased numbers of both $\mathrm{CD}^{+}$and $\mathrm{CD} 8^{+} \mathrm{T}$ cells. $\mathrm{T}$ cells from CKD patients had an immunophenotype compatible with chronic T-cell stimulation as shown by the increased percentage of $\mathrm{CD} 28^{-}, \mathrm{CD}^{2} 7^{+}, \mathrm{HLA}^{-D R}{ }^{+}, \mathrm{CD} 28^{-} \mathrm{HLA}^{-D R^{+}}$, and $\mathrm{CD} 57^{+}$

\footnotetext{
P. Rocha-Pereira

Universidade Beira Interior,

Covilhã, Portugal

V. Miranda $\cdot$ M. d. S. Faria

Fresenius Medical Center, Dinefro-Diálises e Nefrologia, SA,

Porto, Portugal
}

\author{
A. Loureiro \\ Uninefro-Sociedade Prestadora de Cuidados Médicos e de Diálise, \\ SA, \\ Porto, Portugal \\ A. Quintanilha \\ Instituto Ciências Biomédicas Abel Salazar, ICBAS, \\ Universidade do Porto, \\ Porto, Portugal
}


HLA-DR ${ }^{+}$T cells and produce higher levels of IL-2, INF- $\gamma$, and TNF- $\alpha$ after short-term in vitro stimulation, although Th1 cytokines were not detectable in serum. Statistically significant differences were found between responders and nonresponders to rhEPO therapy for total lymphocyte and $\mathrm{CD} 4^{+}$T-lymphocyte counts, albumin (lower in nonresponders) and CRP (higher in nonresponders) levels.

Conclusion CKD patients under hemodialysis present with raised inflammatory markers and decrease of total lymphocyte and $\mathrm{CD}^{+}{ }^{+} \mathrm{T}$-lymphocyte counts when compared with controls. Some of those markers are even further enhanced in nonresponders to rhEPO therapy patients, but resistance to this therapy cannot be justified by a Th1 polarized T-cell response.

Keywords rhEPO Lymphocytes · Inflammation . Resistance to rhEPO therapy

\section{Introduction}

Despite the technological advances in hemodialysis procedures and medical support in the last years, the mortality and morbidity of patients with chronic kidney disease (CKD) remain 10 to 20 times higher than that found in general population, and anemia is still an independent risk factor [1-6].

In the last two decades, the institution of recombinant human erythropoietin (rhEPO) therapy allowed the correction of the anemia in the majority of CKD patients, consequently reducing its associated complications and improving significantly the quality of life. However, more than $25 \%$ of these patients require high doses of rhEPO, and about $5 \%$ to $10 \%$ of them do not respond to the therapy $[4,5-8]$. Many factors were described to be associated with rhEPO therapy resistance, namely, iron, vitamin B12, or folate deficiencies, blood loss, hyperparathyroidism, oxidative stress, aluminum toxicity, infection, and inflammatory conditions [3, 6-11].

Inflammatory stimuli induce the release of cytokines, which in turn causes many systemic changes, including increased synthesis and release of positive acute-phase proteins, such as C-reactive protein (CRP), as well as suppression of negative ones, such as albumin and transferrin [6-11]. The causes for the inflammatory response in hemodialysis patients are not obvious. There are several potential sources, including bacterial contamination of the dialyser, dialyser membrane incompatibility, and infections of the vascular access. However, the dialysis procedure may only be partially responsible because even patients with renal insufficiency who are not yet on dialysis have raised inflammatory markers that rise further after starting regular hemodialysis treatment $[3,12,13]$. This inflammatory response may mobilize iron from erythropoiesis traffic to store sites within the reticuloendothelial system, inhibit erythroid progenitor proliferation and differentiation, blunt the response to erythropoietin, and accelerate removal of erythrocytes coated with immune complexes or immunoglobulins. The erythropoiesis-suppressing effect of the increased activity of pro-inflammatory cytokines associated to this inflammatory condition has been proposed as an important factor associated to rhEPO therapy resistance $[3,6,7,12,14,15]$. Pro-inflammatory cytokines such as interleukin (IL)-1, IL-2, IL-4, IL-6, tumor necrosis factor (TNF)- $\alpha$, and interferon (INF)- $\gamma$ diminish colony formation of burst-forming (BFU-Es) and colonyforming (CFU-Es) unit-erythroid cells, suggesting that these cytokines may cause suppression of erythropoiesis $[3,16,17]$.

Besides inflammation, end-renal failure induces a clinical state of immunodeficiency associated with a higher incidence of infections and a higher mortality due to infectious complications. This immunodeficiency is characterized by a deficient response to some vaccinations, namely, hepatitis B virus. The mechanism responsible for this immune defect is still unknown. However, it is known that lymphopenia is associated to end-renal failure, occurring in the B- and T-lymphocyte compartment, probably due to increased apoptosis [18-20].

There are a considerable number of papers regarding the associations between inflammation and resistance to rhEPO therapy. However, only a few investigated at the same time inflammatory markers, T-cell phenotype, T-cell cytokine production, and cytokine serum levels, and most of these included a very limited number of patients. Furthermore, therapeutic and hemodialysis procedure approaches changed in the last few years, namely, concerning hemodialysis membrane biocompatibility, and these changes could influence the causes of rhEPO resistance.

The aim of this study was to investigate the relationship between resistance to rhEPO therapy and inflammatory markers, T-cell activation-related phenotype, cytokine production by $\mathrm{T}$ cells, and serum cytokine levels in hemodialysis CKD patients.

\section{Materials and Methods}

\section{Subjects and Samples}

Seventy-five individuals were included in this study: 50 hemodialysis CKD patients (25 responders and 25 nonresponders to rhEPO therapy) and 25 healthy controls. The rhEPO maintenance dose for responder patients was $7.51 \pm$ 6.52 $\mathrm{U} \mathrm{kg}^{-1}$ week ${ }^{-1} \mathrm{Hb}^{-1}$ and for nonresponders was $59.40 \pm$ $23.31 \mathrm{U} \mathrm{kg}^{-1}$ week ${ }^{-1} \mathrm{Hb}^{-1}$. 
Blood samples were collected before hemodialysis, with and without anticoagulant [ethylenediamine tetraacetic acid (EDTA) and sodium/lithium heparine] to obtain whole blood, plasma, and serum.

Classification of CKD patients as responders or nonresponders was performed in accordance with the European Best Practice Guidelines [21], which defines resistance to rhEPO as a failure to achieve target hemoglobin levels (11$12 \mathrm{~g} / \mathrm{dl}$ ) with doses of rhEPO higher than $300 \mathrm{IU} \mathrm{kg}^{-1}$ week ${ }^{-1}$ of epoetin or $1.5 \mu \mathrm{g} \mathrm{kg}^{-1}$ week ${ }^{-1}$ of darbopoietin- $\alpha$.

Besides rhEPO therapy, all patients were under iron and folate prophylactic therapies, in accordance to the recommendations of European Best Practice Guidelines [21] to avoid nutrient erythropoietic deficiencies.

The causes of renal failure in patient population were as follows: diabetic nephropathy $(n=16)$, chronic glomerulonephritis $(n=6)$, polycystic kidney disease $(n=5)$, hypertensive nephrosclerosis $(n=3)$, obstructive nephropathy $(n=3)$, pyelonephritis associated with neurogenic bladder $(n=1)$, nephrolithiasis $(n=1)$, chronic interstitial nephritis $(n=1)$, Alport syndrome $(n=1)$, renal vascular disease due to polyarteritis $(n=1)$, and uncertain etiology $(n=12)$. All patients used high-flux polysulfone FX-class dialysers (Fresenius Medical Care, Bad Homburg, Germany). No statistically significant differences where found between responders and nonresponders among CKD patients concerning to age, gender, body weight, body mass index, time on dialysis, urea reduction ratio, $\mathrm{Kt} / V$ and parathyroid hormone serum levels.

Patients with malignancy, hematological disorders, systemic autoimmune diseases, and acute infections were excluded. None of the patients were under vitamin-D therapy. All patients gave their informed consent to participate in this study.

Healthy volunteers, with normal hematological and biochemical values, without any history of renal or inflammatory disease, were used as normal controls and, as far as possible, were age- and gender-matched with CKD patients.

\section{Assays}

Hemoglobin $(\mathrm{Hb})$ and white blood cell (WBC) count was measured using an automatic counter (Sysmex K1000, Hamburg, Germany), and leukocyte differential counts were evaluated in Wright-stained blood films. Serum CRP was measured by immunoturbidimetry (CRP latex HS Roche kit, Roche Diagnostics). Enzyme-linked immunosorbent assay was used for measurement of serum soluble interleukin 2 receptor (sIL2R; Human IL-2 SR $\alpha$, R\&D systems, Minnesota, USA). Serum albumin levels were measured using a colorimetric assay end-point method (Albumin Plus; Roche GmbH, Mannheim, Germany), and the immunoglobulins were quantified by immunoturbidimetry (Tina-quant IgA, Tina-quant IgG, and Tina-quant IgM, Roche $\mathrm{GmbH}$, Mannheim, Germany).

\section{Flow Cytometry}

T-cell cytokine production Heparinised blood cells were cultured for $4 \mathrm{~h}$ in Roswell Park Memorial Institute (RPMI) 1640 medium at $37^{\circ} \mathrm{C}$ in a $5 \% \mathrm{CO}_{2}$ and $95 \%$ humidity sterile environment in the presence of $25 \mathrm{ng} / \mathrm{ml}$ of phorbol-12 myristate 13 -acetate, $1 \mu \mathrm{g} / \mathrm{ml}$ of ionomycin, and $10 \mu \mathrm{g} / \mathrm{ml}$ of brefeldin A (stimulated samples) or only with brefeldin A (unstimulated samples). Immediately after the incubation period, cells were stained with allophycocyanin (APC) conjugated anti-CD3 and fluorescein isothiocyanate (FITC) conjugated anti-CD8 mouse anti-human monoclonal antibodies [MAbs; Becton Dickinson, Biosciences (BDB), San Jose, CA, USA] for $15 \mathrm{~min}$ in the dark at room temperature. After incubation, cells were washed once in $2 \mathrm{ml}$ of phosphate-buffered saline (PBS). After discarding the supernatant, cells were fixed, permeabilized, and stained with phycoerythrin (PE) conjugated MAbs directed against human cytokines (IL-2, TNF- $\alpha$, and INF- $\gamma$ ) or PEconjugated isotype-matched MAbs reagents (negative controls; Pharmingen, San Diego, CA, USA). For this purpose, the Fix \& Perm reagent (Caltag, San Francisco, CA, USA) was used, strictly following the recommendations of the manufacturer. Once stained, cells were washed once in $2 \mathrm{ml}$ of PBS, suspended in $0.5 \mathrm{ml}$ of PBS, and analyzed in the flow cytometer.

T-cell phenotype Cell surface markers were evaluated by flow cytometry with a whole-blood stain-lyse-and-thenwash method, using the florescence-activated cell sorting (FACS) lysing solution (BDB). Cells were stained with anti-CD8 APC or anti-CD4 APC, anti-CD28 PE-cyanin 5 (PC5), anti-HLA-DR PE, and anti-CD57 FITC MAbs (BDB). HLA-DR and CD57 expression were used to evaluate early and late T-cell activation, and absence of CD28 expression on $\mathrm{T}$ lymphocytes was used to quantify the fraction of memory effector $\mathrm{T}$ cells/large granular lymphocytes [22-25].

Serum cytokine levels IL-2, IL-4, IL-6, IL-10, TNF- $\alpha$, and INF- $\gamma$ serum levels were quantified using the $\mathrm{BD}^{\mathrm{TM}}$ Cytometric Bead Array Human Th1/Th2 Cytokine Kit II (BDB).

Data acquisition and analysis Data acquisition was performed in a FACSCalibur flow cytometer, equipped with a 488-nm argon ion and a $635-\mathrm{nm}$ red diode laser, using the CellQUEST ${ }^{\mathrm{TM}}$ software program (BDB). For Tcell phenotype and T-cell cytokine production analysis, 
Table I Blood Cell Count and Immunoglobulin Serum Levels

\begin{tabular}{|c|c|c|c|c|}
\hline & \multirow{2}{*}{$\begin{array}{l}\text { Healthy Controls } \\
(n=25)\end{array}$} & \multicolumn{3}{|l|}{ CKD Patients } \\
\hline & & Total $(n=50)$ & rhEPO Responders $(n=25)$ & rhEPO Nonresponders $(n=25)$ \\
\hline $\mathrm{Hb}(\mathrm{g} / \mathrm{dl})$ & $14.1 \pm 1.3(12.0-17.0)$ & $11.1 \pm 1.8(7.1-15.5)^{*}$ & $11.9 \pm 1.5(9.5-15.5)^{*}$ & $10.3 \pm 1.7(7.1-11.9)^{* * * * *}$ \\
\hline White blood cells $\left(10^{9} / 1\right)$ & $5.8 \pm 1.6(3.5-9.6)$ & $6.2 \pm 2.2(3.0-12.3)$ & $6.4 \pm 1.9(4.2-11.5)$ & $6.0 \pm 2.4(3.0-12.3)$ \\
\hline Lymphocytes $\left(10^{9} / 1\right)$ & $2.2 \pm 0.7(1.1-3.5)$ & $1.4 \pm 0.6(0.4-3.1)^{*}$ & $1.6 \pm 0.5(0.5-3.0)^{* *}$ & $1.2 \pm 0.6(0.4-3.1)^{* * * * *}$ \\
\hline $\mathrm{CD}^{+} \mathrm{T}$ cells $\left(10^{9} / 1\right)$ & $1.6 \pm 0.7(0.5-3.0)$ & $1.0 \pm 0.5(0.2-2.4)^{* *}$ & $1.2 \pm 0.6(0.2-2.4)$ & $0.9 \pm 0.5(0.2-2.2)^{* * * * * *}$ \\
\hline $\mathrm{CD}^{+} \mathrm{T}$ cells $\left(10^{9} / 1\right)$ & $1.1 \pm 0.5(0.3-2.2)$ & $0.7 \pm 0.3(0.1-1.16)^{* *}$ & $0.8 \pm 0.4(0.1-1.6)^{* *}$ & $0.6 \pm 0.3(0.1-1.13)^{* * * * * *}$ \\
\hline $\mathrm{CD}^{+} \mathrm{T}$ cells $\left(10^{9} / 1\right)$ & $0.5 \pm 0.2(0.2-0.8)$ & $0.3 \pm 0.2(0.1-0.9)^{* *}$ & $0.3 \pm 0.2(0.1-0.7)$ & $0.3 \pm 0.2(0.1-0.9)^{* *}$ \\
\hline $\mathrm{CD} 4 / \mathrm{CD} 8$ ratio & $2.7 \pm 1.0(1.3-4.2)$ & $3.0 \pm 1.4(0.8-7.9)$ & $2.9 \pm 1.7(1.2-7.9)$ & $2.6 \pm 1.3(0.8-6.0)$ \\
\hline Monocytes $\left(10^{9} / 1\right)$ & $0.2 \pm 0.1(0.1-0.4)$ & $0.4 \pm 0.2(0.2-0.9)^{* *}$ & $0.4 \pm 0.1(0.2-0.7)^{*}$ & $0.3 \pm 0.2(0.2-0.9)$ \\
\hline Neutrophils $\left(10^{9} / 1\right)$ & $3.0 \pm 1.0(1.5-5.2)$ & $4.1 \pm 1.7(1.8-8.9)^{* *}$ & $4.1 \pm 1.7(2.0-8.9)^{* *}$ & $4.1 \pm 1.8(1.8-8.3)^{* *}$ \\
\hline Eosinophils $\left(10^{9} / 1\right)$ & $0.2 \pm 0.3(0.0-1.6)$ & $0.2 \pm 0.2(0.0-1.1)$ & $0.2 \pm 0.2(0.0-1.1)$ & $0.2 \pm 0.1(0.0-0.5)$ \\
\hline Neutrophil/Lymphocyte ratio & $1.37 \pm 0.51(0.56-2.66)$ & $3.34 \pm 1.92(0.96-8.25)^{*}$ & $2.80 \pm 1.14(1.28-8.19)^{*}$ & $3.88 \pm 2.05(0.96-8.25)^{* * * * *}$ \\
\hline $\operatorname{IgG}(\mathrm{mg} / \mathrm{dl})$ & $977 \pm 161(688-1279)$ & $1078 \pm 353(509-2163)$ & $1043 \pm 315(633-2163)$ & $1112 \pm 392(509-1986)$ \\
\hline $\operatorname{IgA}(\mathrm{mg} / \mathrm{dl})$ & $215 \pm 86(77-387)$ & $275 \pm 126(91-653)$ & $275 \pm 119(91-542)$ & $275 \pm 136(104-653)$ \\
\hline $\operatorname{IgM}(\mathrm{mg} / \mathrm{dl})$ & $122 \pm 65(33-277)$ & $106 \pm 78(29-518)$ & $100 \pm 57(29-276)$ & $113 \pm 95(30-518)$ \\
\hline
\end{tabular}

Results are presented as mean \pm one standard deviation (minimum-maximum)

$* p<0.0001$ vs controls

$* * p<0.05$ vs controls

$* * * p<0.05$ vs responders

the Paint-A-Gate PRO software program (BDB) was used. To quantify the expression of costimulatory molecules and activation-related markers on $\mathrm{T}$ cells, the percentage of $\mathrm{HLA}-\mathrm{DR}^{+}, \mathrm{CD} 28^{+}$, and $\mathrm{CD} 57^{+}$cells were recorded after gating for $\mathrm{CD} 8^{+}$and $\mathrm{CD} 4^{+} \mathrm{T}$ lymphocytes. Evaluation of cytokine production by $\mathrm{CD}^{+}$and $\mathrm{CD} 4^{+} \mathrm{T}$ cells was based on the percentage of cytokine ${ }^{+}$cells within $\mathrm{CD}^{+} \mathrm{CD}^{+}$and $\mathrm{CD}^{+} \mathrm{CD}^{-}$lymphocytes, respectively. Serum cytokine levels analysis was performed using the $\mathrm{BD}^{\mathrm{TM}}$ CBA Software.
Statistical Analysis

For statistical analysis, we used the Statistical Package for Social Sciences, version 14.0. Kolmogorov-Smirnov statistics was used to evaluate sample normality distribution. Multiple comparisons between groups were performed by one-way analysis of variance supplemented with Tukey's honestly significant difference (HSD) post-hoc test. For single comparisons, we used the Student's $t$ test whenever the parameters presented a Gaussian distribution and the

Table II Expression of HLA-DR, CD57 and CD28 Molecules on Blood CD4 ${ }^{+}$and CD8 ${ }^{+}$T Cells

\begin{tabular}{|c|c|c|c|c|}
\hline & \multirow[t]{2}{*}{ Healthy Controls $(n=12)$} & \multicolumn{3}{|l|}{ CKD Patients } \\
\hline & & Total $(n=24)$ & rhEPO Responders $(n=12)$ & rhEPO Nonresponders $(n=12)$ \\
\hline \multicolumn{5}{|l|}{$\% \mathrm{CD}^{+}{ }^{+} \mathrm{T}$ cells } \\
\hline HLA-DR ${ }^{+}$ & $8.7 \pm 4.2(4.7-18.6)$ & $17.4 \pm 7.4(6.8-41.3)^{*}$ & $16.4 \pm 9.1(6.8-41.3)^{*}$ & $18.8 \pm 4.2(12.8-25.8)^{*}$ \\
\hline $\mathrm{CD} 57^{+}$ & $2.4 \pm 3.4(0.4-12.6)$ & $9.0 \pm 7.7(0.6-32.0)^{*}$ & $8.2 \pm 8.9(0.7-32.0)^{*}$ & $10.8 \pm 6.7(0.6-22.1)^{*}$ \\
\hline $\mathrm{CD} 28^{-}$ & $0.9 \pm 0.9(0.3-3.1)$ & $7.0 \pm 7.0(0.1-23.5)^{*}$ & $6.6 \pm 5.5(0.1-17.0)^{*}$ & $8.6 \pm 8.5(0.1-23.5)^{*}$ \\
\hline $\mathrm{CD} 7^{+} \mathrm{HLA}^{-D R^{+}}$ & $23.7 \pm 13.6(0.3-44.2)$ & $44.9 \pm 19.8(13.9-8.3)^{*}$ & $43.3 \pm 17.8(19.7-68.3)^{*}$ & $47.2 \pm 23.7(13.9-67.4)^{*}$ \\
\hline $\begin{array}{l}\mathrm{CD}^{2} 8^{-} \mathrm{HLA}^{-\mathrm{DR}^{+}} \\
\% \mathrm{CD} 8^{+} \mathrm{T} \text { cells }\end{array}$ & $25.3 \pm 23.2(9.7-72.2)$ & $43.6 \pm 19.5(16.7-77.0)^{*}$ & $42.8 \pm 20.4(19.9-69.1)^{*}$ & $44.7 \pm 19.8(16.7-77.0)^{*}$ \\
\hline HLA-DR ${ }^{+}$ & $25.1 \pm 12.8(10.4-44.4)$ & $45.7 \pm 16.5(17.3-73.5)^{*}$ & $41.4 \pm 17.4(17.3-65.2)^{*}$ & $51.5 \pm 14.1(32.1-73.5)^{*}$ \\
\hline $\mathrm{CD}_{57^{+}}$ & $21.1 \pm 13.5(4.9-43.4)$ & $38.3 \pm 15.9(14.2-60.0)^{*}$ & $34.8 \pm 11.2(16.4-52.9)^{*}$ & $44.7 \pm 19.4(14.2-60.0)^{*}$ \\
\hline $\mathrm{CD} 28^{-}$ & $28.4 \pm 13.7(11.8-57.2)$ & $44.0 \pm 22.9(7.5-85.7)^{*}$ & $41.3 \pm 19.0(15.0-64.2)^{*}$ & $49.5 \pm 26.9(7.5-85.7)^{*}$ \\
\hline CD28 ${ }^{-}$HLA-DR $^{+}$ & $33.7 \pm 18.7(0.1-61.3)$ & $54.8 \pm 19.3(22.6-86.0)^{*}$ & $50.4 \pm 18.0(22.6-73.4)^{*}$ & $58.9 \pm 20.7(31.4-86.0)^{*}$ \\
\hline $\mathrm{CD} 7^{+} \mathrm{HLA}^{-\mathrm{DR}^{+}}$ & $35.1 \pm 21.2(0.1-66.2)$ & $54.9 \pm 18.2(18.0-81.7)^{*}$ & $50.2 \pm 16.2(18.0-72.1)$ & $58.5 \pm 19.8(27.2-81.7)^{*}$ \\
\hline
\end{tabular}

Results are presented as mean \pm one standard deviation (minimum-maximum) ${ }^{*} p<0.05$ vs controls 
Table III Inflammatory Markers and Serum Cytokine Levels of Studied Subjects

\begin{tabular}{lllll}
\hline \multirow{2}{*}{ Healthy Controls $(n=25)$} & \multicolumn{2}{l}{ CKD patients } & \\
\cline { 3 - 5 } & & Total $(n=50)$ & rhEPO Responders $(n=25)$ & rhEPO Nonresponders $(n=25)$ \\
\hline Albumin $(\mathrm{g} / \mathrm{dl})$ & $\mathrm{NM}$ & $3.8 \pm 0.4(2.7-4.5)$ & $4.0 \pm 0.4(2.9-4.5)$ & $3.7 \pm 0.4(2.7-4.2)^{* * *}$ \\
CPR $(\mathrm{mg} / \mathrm{dl})$ & $1.75(0.76-4.47)$ & $5.75(1.90-14.01)^{*}$ & $3.20(1.73-7.23)^{* *}$ & $10.14(3.82-38.99)^{* * * * *}$ \\
sIL2R $(\mathrm{nmol} / \mathrm{l})$ & $758 \pm 235(324-1290)$ & $4199 \pm 1762(1795-8377)^{*}$ & $4005 \pm 1835(1795-8377)^{*}$ & $4394 \pm 1701(2232-8265)^{*}$ \\
IL-2 $(\mathrm{pg} / \mathrm{ml})$ & $2.5 \pm 3.0(0.0-9.3)$ & $\mathrm{ND}$ & $\mathrm{ND}$ & $\mathrm{ND}$ \\
IL-4 $(\mathrm{pg} / \mathrm{ml})$ & $\mathrm{ND}$ & $\mathrm{ND}$ & $\mathrm{ND}$ & $\mathrm{ND}$ \\
IL-6 $(\mathrm{pg} / \mathrm{ml})$ & $1.90(0-3.75)$ & $7.80(3.85-15.05)^{*}$ & $5.75(3.83-13.95)^{*}$ & $8.80(4.55-21.30)^{*}$ \\
IL-10 $(\mathrm{pg} / \mathrm{ml})$ & $1.20(0-2.80)$ & $1.10(0-2.15)$ & $0.0(0-1.6)$ & $1.40(0-2.25)^{* * *}$ \\
TNF- $\alpha(\mathrm{pg} / \mathrm{ml})$ & $1.40(0-3.55)$ & $\mathrm{ND}$ & $\mathrm{ND}$ & $\mathrm{ND}$ \\
INF- $\gamma(\mathrm{pg} / \mathrm{ml})$ & $\mathrm{ND}$ & $\mathrm{ND}$ & $\mathrm{ND}$ & $\mathrm{ND}$ \\
\hline
\end{tabular}

Results are presented as mean \pm one standard deviation (minimum-maximum) or as median values (inter-quartile range). Zero values represent samples in which serum levels of the mentioned cytokine were undetectable: IL-2 (7 out of 18 controls' and all patients' samples); IL-6 (7 out of 18 controls' samples); TNF- $\alpha$ (8 out of 18 controls' and all patients' samples); IL-10 (8 out of 18 controls' and 25 out of 50 patients' samples; 17 out of 25 responders and 8 out of 25 nonresponders)

$N M$ Not made; $N D$ not detected (limit of detection $<1 \mathrm{pg} / \mathrm{ml}$ )

$* p<0.0001$, vs controls

$* * p<0.05$, vs controls

$* * * p<0.05$ vs responders

Mann-Whitney $U$ test in the case of a non-Gaussian distribution. Significance was accepted at $p$ less than 0.05 .

\section{Results}

The hematological characteristics of the three groups studied are summarized in Table I. Hemodialysis CKD patients were more anemic than controls, and nonresponder patients were even more anemic than responder patients. No difference was found between the three groups of patients concerning the WBC count. However, CKD patients showed lymphopenia as well as increased monocyte and neutrophil counts and increased neutrophil/lymphocyte ratio, as compared to controls. Lymphopenia observed in CKD patients results at least in part from a decrease in total circulating $\mathrm{CD}^{+} \mathrm{T}$ lymphocytes and affects both the $\mathrm{CD} 4^{+}$and the $\mathrm{CD} 8^{+} \mathrm{T}$-cell subsets $(p<0.05)$. Statistically significant differences were found between responders and nonresponders to rhEPO therapy, concerning total lymphocyte and $\mathrm{CD} 4^{+} \mathrm{T}$-cell counts (lower for nonresponders; $p<0.05$ ), and to neutrophil/ lymphocyte ratio (higher for nonresponders; $p<0.05$ ). No statistically significant differences were found between the three groups of individuals concerning immunoglobulin serum levels (Table I).

CKD patients showed a statistically significant increase $(p<0.05)$ in the proportion of CD28 $8^{-}, \mathrm{CD} 57^{+}, \mathrm{HLA}-\mathrm{DR}^{+}$, CD28 ${ }^{-} \mathrm{HLA}_{-} \mathrm{DR}^{+}$and $\mathrm{CD}^{+} 7^{+} \mathrm{HLA}^{-\mathrm{DR}^{+}} \mathrm{T}$ cells when compared to controls, both in the $\mathrm{CD} 4^{+}$and in the $\mathrm{CD} 8^{+}$ T-cell compartments (Table II). No statistically significant differences were found between responders and nonresponders to rhEPO concerning expression of CD28 co-stimulatory, and CD57 and HLA-DR cell-surface activation-related molecules.

CKD patients showed a statistically significant increase in serum levels of CRP, sIL2R, and IL-6 as compared to
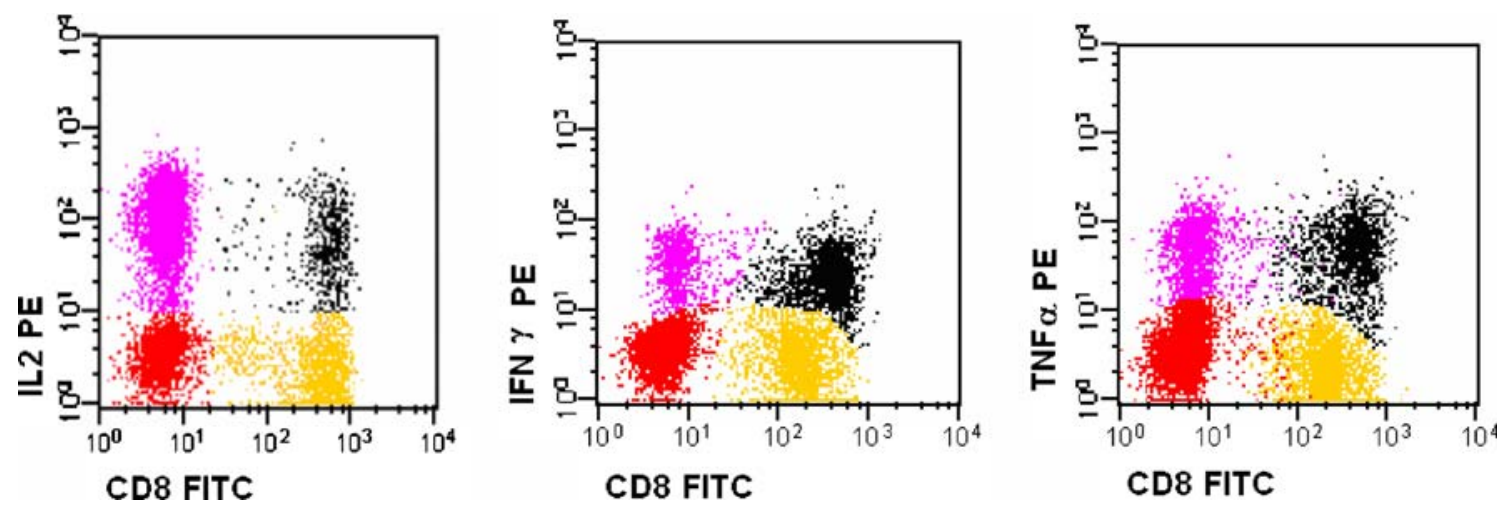

Fig. 1 Illustrative dot plots showing the IL-2, INF- $\gamma$, and TNF- $\alpha$ expression on $\mathrm{CD} 8^{+}$and $\mathrm{CD} 8^{-}$cells, after gating on $\mathrm{CD} 3^{+} \mathrm{T}$ lymphocytes. Red dots $\mathrm{CD}^{+} \mathrm{CD}^{-}$Cytokine ${ }^{-}$; yellow dots $\mathrm{CD}^{+} \mathrm{CD}^{+}$Cytokine $^{-}$; violet dots $\mathrm{CD}^{+} \mathrm{CD}^{-}$Cytokine $^{+}$; black dots $\mathrm{CD}^{+} \mathrm{CD}^{+} \mathrm{Cytokine}^{+} \mathrm{T}$ cells 
controls $(p<0.0001$; Table III). In contrast, serum levels of IL-2 and TNF- $\alpha$ were lower in CKD patients, these Th1 cytokines being detected in 11 and 10 out of 18 control samples, respectively, whereas in none of the CKD patients' samples. Concerning IL-10, no differences were found between CKD patients and controls, this cytokine being detected in 10 out of 18 controls' and in 25 out of 50 CKD patients' samples. Serum levels of IL- 4 and INF- $\gamma$ were undetectable in both control's and patient's samples.

$\mathrm{T}$ cells from CKD patients produced higher amounts of IL-2, TNF- $\alpha$, and IFN- $\gamma$ after short-term in vitro stimulation as compared to controls (Figs. 1 and 2). Statistically significant differences $(p<0.05)$ were observed for IL-2, INF- $\gamma$, and TNF- $\alpha$ in the case of $\mathrm{CD}^{+} \mathrm{T}$ cells but only for IL- 2 and TNF- $\alpha$ in the case of $\mathrm{CD} 4^{+} \mathrm{T}$ cells.

When comparing responders and nonresponders CKD patients, we found that nonresponders showed decreased serum levels of albumin $(p<0.01)$ and increased CRP $(p<$ $0.05)$ and IL-10 $(p<0.05)$ serum levels, this cytokine being detected in 17 of the 25 analyzed samples, as compared to 8 out of the 25 responder's samples (Table III). No differences were observed between responders and nonresponders in the levels of the other soluble mediators, neither on the ability to produce Th1 cytokines after shortterm in vitro stimulation.

\section{Discussion}

In this study, we demonstrated that CKD patients under hemodialysis treatment show neutrophilia, increased neutrophil/lymphocyte ratio, and higher levels of IL-6, sIL2R, and CRP pro-inflammatory molecules in the serum, and decreased albumin serum levels, confirming the presence of an inflammatory process. The fact that nonresponders had higher CRP and lower albumin serum levels as compared to responders would suggest a relationship between resistance to rhEPO therapy and the magnitude of the inflammatory response, already described in literature [13, 14, 26-28].

In addition, this study demonstrated that CKD patients have lower number of total lymphocytes, $\mathrm{CD}^{+}$and $\mathrm{CD} 8^{+}$ $\mathrm{T}$ lymphocytes, when compared to controls, although statistically significant differences between responders and nonresponders to rhEPO therapy were found only for total lymphocytes and $\mathrm{CD}^{+} \mathrm{T}$ cells, which were lower in nonresponders. $\mathrm{T}$ and $\mathrm{B}$ lymphopenia have been previously described in literature in CKD patients, associated with renal-replacement therapy [29, 30]. B lymphopenia has been associated with stage 5 of CKD and T lymphopenia to a selective depletion of naïve $\mathrm{CD} 4^{+}$and $\mathrm{CD} 8^{+} \mathrm{T}$ lymphocytes and $\mathrm{CD}^{+}$central memory population [31]. There are some possible explanations for lymphocyte depletion in CKD patients, namely, increased turnover, disturbance of
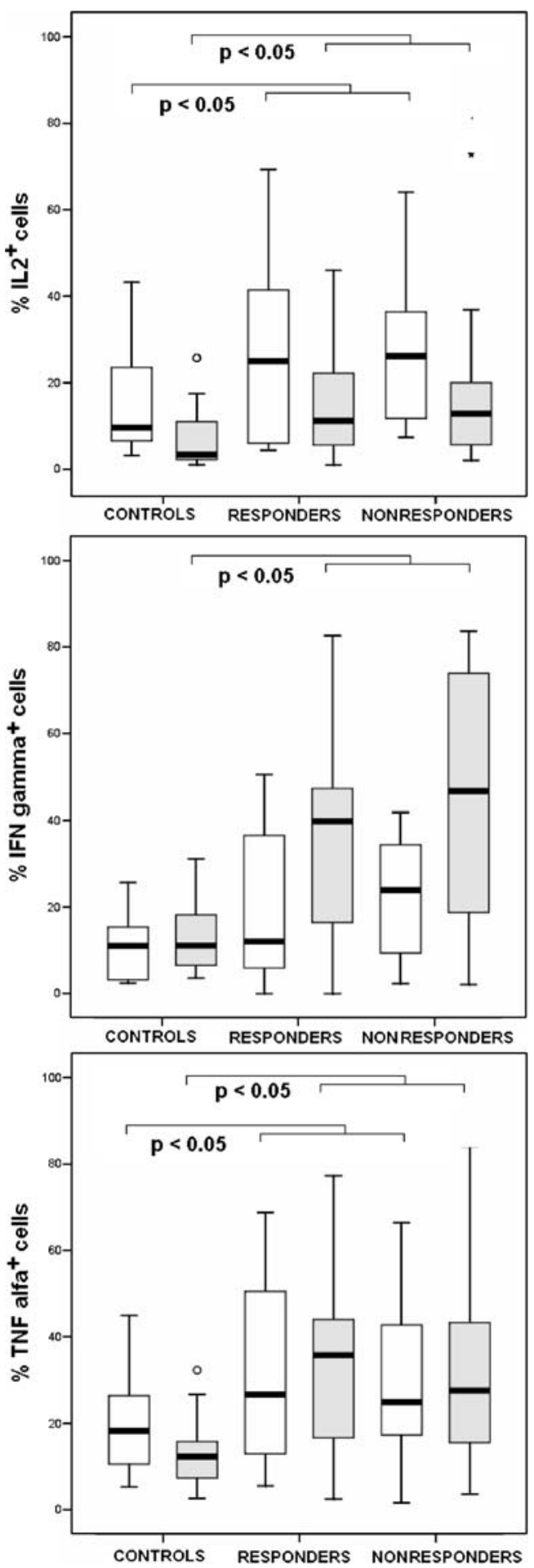

Fig. 2 Percentage of Cytokine ${ }^{+}$cells among $\mathrm{CD}^{+}\left(\mathrm{CD}^{+} \mathrm{CD}^{-}\right.$; white bars) and $\mathrm{CD}^{+}\left(\mathrm{CD}^{+} \mathrm{CD}^{+}\right.$; grey bars $) \mathrm{T}$ cells after short-term in vitro stimulation with phorbol-12 myristate 13 -acetate plus Ionomycin in controls, as well as in responder and nonresponder CKD patients. Boxplot shows median value (horizontal line in box) and first and third quartiles (inferior and superior lines of the box, respectively)

lymphocyte homeostasis due to uremia and increased peripheral lymphocyte apoptosis associated with activation stimulus [14, 31-35]. This lymphocyte depletion could be 
exacerbated in nonresponders, justifying the difference found between the two groups of patients concerning total lymphocytes and $\mathrm{CD} 4^{+} \mathrm{T}$ lymphocytes.

Increased proportions of both early (HLA-DR) and lateactivation (CD57) markers on both $\mathrm{CD} 4^{+}$and $\mathrm{CD} 8^{+}$T-cell subsets are compatible with an enhanced continuous activation state in CKD patients [22]. This probably results from persistent antigen stimulation/chronic inflammation associated with hemodialysis and/or chronic renal failure, which probably also justifies the increase in the fraction of memory effector $\mathrm{T}$ cells/large granular lymphocytes, as shown by the higher percentage of $\mathrm{CD} 4^{+} / \mathrm{CD} 28^{-}$and $\mathrm{CD} 8^{+} /$ $\mathrm{CD} 28^{-} \mathrm{T}$ cells observed in hemodialysis $\mathrm{CKD}$ patients when compared to controls [25]. Curiously, higher levels of expression of HLA-DR and CD57 were observed not only on total $\mathrm{CD} 4^{+}$and $\mathrm{CD} 8^{+} \mathrm{T}$ cells, but also on $\mathrm{CD} 4^{+} / \mathrm{CD} 28^{-}$ and $\mathrm{CD} 8^{+} / \mathrm{CD} 28^{-}$T-cell subsets. On literature, we found only one paper [14] describing cytokine and CD28 T-cell expression in CKD patients, and the authors showed statistically significant differences between responders and nonresponders to rhEPO therapy. However, in our study, no differences were found between the two groups of patients. These differences could be due to the difference between studied CKD patient population, namely, concerning the existence of other rhEPO resistance-related factors.

In accordance to their enhanced activation state, $\mathrm{T}$ cells from CKD patients under hemodialysis treatment show an enhanced ability to produce Th1-related cytokines (IL-2, INF- $\gamma$, and TNF- $\alpha$ ) after short-term in vitro stimulation, although these cytokines were undetectable in serum. This increased capacity to produce Th1 cytokines could justify, at least in part, the anemia found in CKD patients. In fact, these cytokines are described to be associated to an inhibitory effect to the formation of CFU-Es and BFU-Es [12-14, 16]. However, this enhanced capacity to produce cytokines is not associated to the refractoriness to rhEPO therapy, as previously described in nonresponder CKD patients [7].

In conclusion, our results show that CKD patients have an enhanced inflammatory response as well as evidence of Th1 polarized T-cell activation process and suggest that resistance to rhEPO therapy is associated to inflammation markers and $\mathrm{CD} 4{ }^{+}$lymphopenia but cannot be ascribed to an enhanced T-cell activation state neither to a mediated Th1 response. Further studies are required to understand the mechanism of lymphocyte loss and its consequences in the response to rhEPO therapy.

\footnotetext{
Acknowledgments The authors are grateful to Amgen for financial support and to the nurses of Fresenius Medical Center, DinefroDiálises e Nefrologia, SA and Uninefro-Sociedade Prestadora de Cuidados Médicos e de Diálise, SA, for technical support. This study was supported by a $\mathrm{PhD}$ grant (SFRH/BD/27688/2006) attributed to E. Costa by Fundação para a Ciencia e Tecnologia (FCT) and Fundo Social Europeu.
}

\section{References}

1. Kerr PG. Renal anaemia: recent developments, innovative approaches and future directions for improved management. Nephrology. 2006;11:542-8.

2. Macdougall IC. Present and future strategies in the treatment of renal anaemia. Nephrol Dial Transpl. 2001;16(suppl 5):50-5.

3. Macdougall IC, Cooper AC. Erythropoietin resistance: the role of inflammation and pro-inflammatory cytokines. Nephrol Dial Transplant. 2002;17(Suppl 11):39-43.

4. Foley RN, Parfrey PS, Sarnak MJ. Clinical epidemiology of cardiovascular disease in chronic renal failure. Am J Kidney Dis. 1998;32(suppl 3):S112-9.

5. Foley RN, Parfrey PS, Harnett JD, Kent GM, Murray DC, Barre PE. The impact of anemia on cardiomyopathy morbidity and mortality in end-stage renal disease. Am J Kidney Dis. 1996; 28:53-61.

6. Smrzova J, Balla J, Bárány P. Inflammation and resistance to erythropoiesis-stimulting agents - what do we know and what needs to be clarified. Nephrol Dial Transpant. 2005;20(Suppl 8):viii2-7.

7. Cooper AC, Mikhail A, Lethbridge MW, Kemeny DM, Macdougall IC. Increased expression of erythropoiesis inhibiting cytokines (IFN- $\gamma$, TNF- $\alpha$, IL-10, and IL-13) by T cells in patients exhibiting a poor response to erythropoietin therapy. J Am Soc Nephrol. 2003;14:1776-84.

8. Macdougal IC. Poor response to erythropoietin: practical guidelines on investigation and management. Nephrol Dial Transplant. 1995;10:607-14.

9. Drueke TB. R-HuEPO hyporesponsiveness: who and why. Nephrol Dial Transplant. 1995;10(suppl 2):S62-8.

10. Danielson B. R-HuEPO hyporesponsiveness: who and why. Nephol Dial Transplant. 1995;10(suppl 2):S69-73.

11. Fishbane S. Hyporesponsiveness to recombinant human erythropoietin in dialysis patients. Dial Transplant. 2000;29:545-8.

12. Schindler R, Senf R, Frei U. Influencing the inflammatory response of haemodialysis patients by cytokine elimination using large-pore membranes. Nephrol Dial Transplant. 2002;17:17-9.

13. Gunnell J, Yeun JY, Depner TA, Kaysen GA. Acute-phase response predicts erythropoietin resistance in hemodialysis and peritoneal dialysis patients. Am J Kidney Dis. 1999;33:63-72.

14. Cooper AC, Breen CP, Vyas B, Ochola J, Kemeny DM, Macdougall IC. Poor response to recombinant erythropoitin is associated with loss of T-lymphocyte CD28 expression and altered interleukin-10 production. Nephrol Dial Transplant. 2003; $18: 133-40$

15. Descamps-Latscha B, Herbelin A, Nguyen AT, Roux-Lombard P, Zingraff J, Moynot A, Verger C, Dahmane D, Groote D, Jungers P, Dayer JM. Balance between IL- $1 \beta$, TNF- $\alpha$, and their specific inhibitors in chronic renal failure and maintenance dialysis. J Immunology. 1995;154:882-92.

16. Means RT Jr, Krantz SB. Inhibition of human erythroid colony forming units by interferons $\alpha$ and $\beta$ : differing mechanisms despite shared receptor. Exp Haematol. 1996;24:204-8.

17. Allen DA, Breen C, Yaqoob MM, Macdougall IC. Inhibition of CFU-E colony formation in uremic patients with inflammatory disease: role of INF- $\gamma$ and TNF- $\alpha$. J Invest Med. 1999;47:204-11.

18. Meier P, Dayer E, Blanc E, Wauters JP. Early T cell activation correlates with expression of apoptosis markers in patients with end-stage renal disease. J Am Soc Nephol. 2002;13:204-12.

19. Waltzer WC, Bachvaroff RJ, Raisbeck AP, Egelandsdal B, Pullis C, Shen L, Rapaport FT. Immunological monitoring in patients with end-stage renal disease. J Clin Immunol. 1984;4:364-8.

20. Litjens NHR, van Druninger CJ, Betjes MGH. Progressive loss of renal function is associated with activation and depletion of naïve T lymphocytes. Clinical Immunology. 2006;118:83-91. 
21. Locatelli F, Aljama P, Barany P, European Best Practice Guidelines Working Group, et al. Revised European best practice guidelines for the management of anaemia in patients with chronic renal failure. Nephrol Dial Transplant. 2004;19(Suppl 2):ii1-47.

22. d'Angeac AD, Monier S, Pilling D, Travaglio-Encinoza A, Reme T, Salmon M. CD57 ${ }^{+}$T lymphocytes are derived from CD57precursors by differentiation occurring in late immune responses. Eur J Immunol. 1997;24:1503-11.

23. Lima M, Teixeira Mdos A, Queiros ML, Santos AH, Goncalves C, Correia J, Farinha F, Mendonca F, Soares JM, Almeida J, Orfao A, Justica B. Immunophenotype and TCR-Vbeta repertoire of peripheral blood T-cells in acute infectious mononucleosis. Blood Cells Mol Dis. 2003;30:1-12.

24. Lima M, Almeida J, Teixeira MA, Santos AH, Queiros ML, Fonseca S, Moura J, Goncalves M, Orfao A, Pinto Ribeiro AC. Reactive phenotypes after acute and chronic NK-cell activation. J Biol Regul Homeost Agents. 2004;18:331-4.

25. Romero P, Zippelius A, Kurth I, Pittet MJ, Touvrey C, Iancu EM, Corthesy P, Devevre E, Speiser DE, Rufer N. Four functionally distinct populations of human effector-memory $\mathrm{CD} 8^{+} \mathrm{T}$ lymphocytes. J Immunol. 2007;178:4112-9.

26. Bárány P. Inflammation, serum C-reactive protein, and erythropoietin resistance. Nephrol Dial Transplant. 2001;16:224-7.

27. Spittle MA, Hoenich NA, Handelman GJ, Adhikarla R, Homel P, Levin NW. Oxidative stress and inflammation in hemodialysis patients. Am J Kidney Dis. 2001;38:1408-13.

28. Reddan DN, Klassen PS, Szczech LA, Coladonato JA, O'Shea S, Owen WF Jr, Lowrie EG. White blood cells as a novel mortality predictor in haemodialysis patients. Nephrol Dial Transplant. 2003;18:1167-73.
29. Fernandez-Fresnedo G, Ramos MA, Gonzalez-Pardo MC, de Francisco AL, Lopez-Hoyos M, Aris M. B lymphopenia in uremia is related to an accelerated in vitro apoptosis and dysregulation of Bcl-2. Nephrol Dial Transplant. 2000;15:502-10.

30. Kurz $P$, Kohler $H$, Meuer S, Hutteroth $T$, Meyer zum Buschenfelde KH. Impaired cellular immune response in chronic renal failure: evidence for a $\mathrm{T}$ cell defect. Kidney Int. 1986;29:1209-14.

31. Litjens NHR, van Druningen CJ, Betjes MGH. Progressive loss of renal function is associated with activation and depletion of naïve $\mathrm{T}$ lymphocytes. Clinical Immunology. 2006;118:83-91.

32. Kang I, Hong MS, Nolasco H, Park SH, Dan JM, Choi JY, Craft J. Age-associated change in the frequency of memory $\mathrm{CD}^{+}{ }^{+} \mathrm{T}$ cells impairs long term $\mathrm{CD} 4^{+} \mathrm{T}$ cell responses to influenza vaccine. $\mathrm{J}$ Immunol. 2004;173:673-81.

33. Napolitano LA, Grant RM, Dreeks SG, Schmidt D, De Rosa SC, Herzenberg LA, Herndier BG, Andersson J, McCune JM. Increased production of IL-7 accompanies HIV-1-mediated T-cell depletion: implications for T-cell homeostasis. Nat Med. 2001;7:73-9.

34. Moser B, Roth G, Brunner M, Lilaj T, Deicher R, Wolner E, Kovarik J, Boltz-Nitulescu G, Vychytil A, Ankersmit HJ. Aberrant $\mathrm{T}$ cell activation and heightened apoptotic turnover in end-stage renal failure patients: a comparative evaluation between non-dialysis, haemodialysis, and peritoneal dialysis. Biochem Biophys Res Commun. 2003;308:581-5.

35. Jiang Q, Li WQ, Aiello FB, Mazzucchelli B, Asefa B, Khaled AR, Durum SK. Cell biology of IL-7, a key lymphotrophim. Cytokine Growth Factor Rev. 2005;16:513-33. 